Research Article

\title{
Chinese Immigration to California: Welcomed Workers, Shunned Immigrants
}

Anthony W. Baker

MA in history, Indiana State University

Corresponding Author: Anthony W. Baker, E-mail: bakera3312@gmail.com

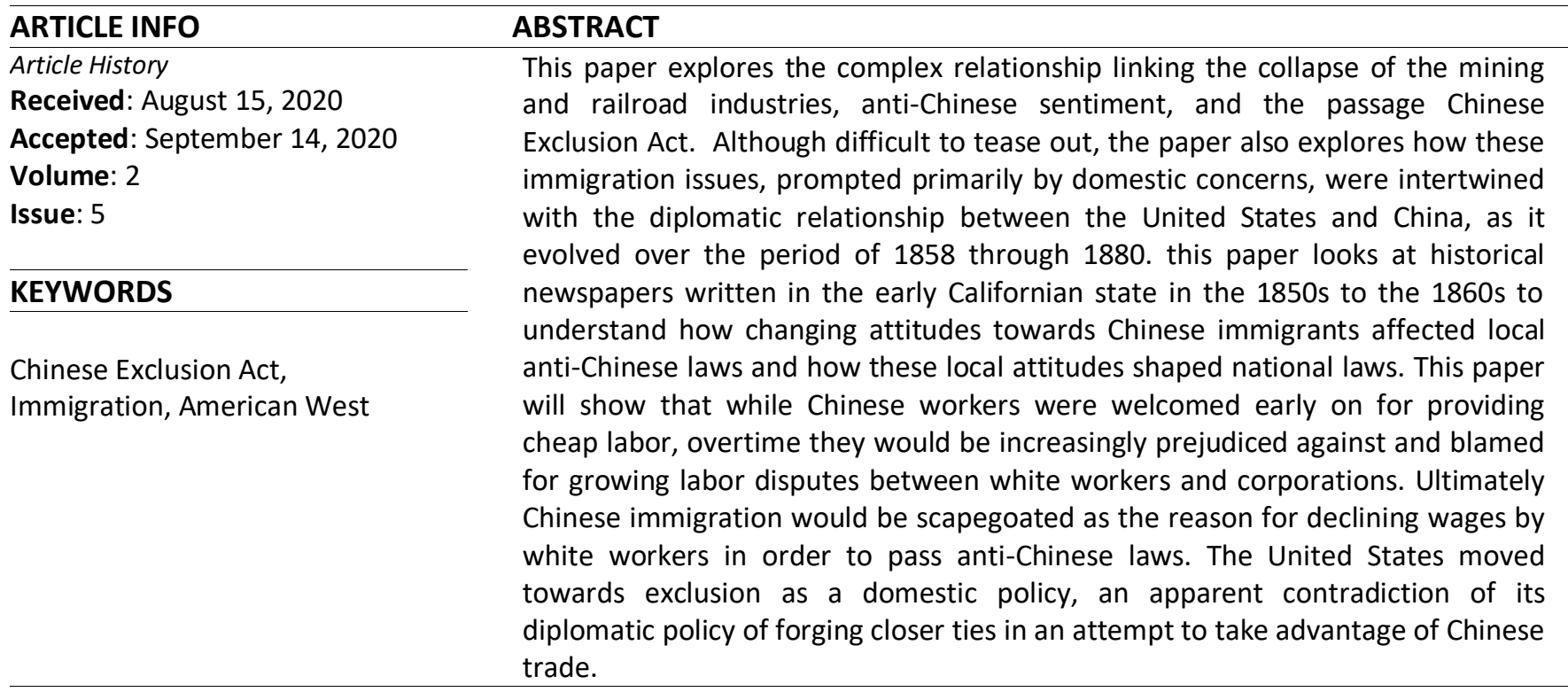

\section{Introduction}

Chinese immigrants to the American West in the mid- to late-19 ${ }^{\text {th }}$ century aided the process of integrating these territories into the union. They built the railroads, mined for gold and aided in developing the local economy. Despite the critical role, they played in the West, popular representations of the West focus on settlers, cowboys, Native Americans, goldminers, and railroads, rarely do they portray ethnic Chinese. Even when ethnic Chinese are included they are members of gangs, improvised, and perhaps in an opium den. Even historians have neglected to present Chinese immigrants within the context of the American West (Dippie, 1989).

However, historians, novelists and movie directors are just following trends set at the time. For instance, in 1869, the first transcontinental railroad was joined. In the photo to commemorate the accomplishment not one Chinese immigrant was present, even though the Central Pacific Railroad's workforce was 90 percent Chinese laborers, totaling more than ten thousand people. The famous photograph that marks the occasion "Celebration of the meeting of the railroad in Promontory Summit, Utah, May 1869", represents the American attitudes towards the Chinese at the time. Chinese laborers were needed to provide cheap labor. However, once the work was done, they were excluded from daily life (Pegler-Gordon, 2006).

From 1850 until the passage of the Chinese Exclusion Act in 1882, Chinese laborers immigrated to the American West looking for work. Despite racial prejudices and low wages, many immigrants flourished in their new nation. However, as the need for cheap labor diminished, local businesses no longer attempted to prevent the passage of local anti-Chinese laws. These local anti-Chinese laws led to the Chinese Exclusion Act. This act of Congress was passed because, per the law, Chinese immigration "endangers the good order of certain localities within the territory thereof". The Chinese Exclusion Act says, "until the expiration of ten years next after the passage of this act, the coming of Chinese laborers to the United States be,

K C AL-KINDI CENTER $\mathbf{R}$ D FOR RESEARCH AND Your gateway to world-class research
Published by Al-Kindi Center for Research and Development. Copyright (c) the author(s). This is an open access article under CC BY license (https://creativecommons.org/licenses/by/4.0/) 
and the same is hereby, suspended". Those ten years would pass, and in 1892 the law would be extended, the law was repealed in 1943 (Chinese Exclusion Act).

After 1850, the California economy became more dynamic with the creation of the mining and railroad industries. These industries required a massive workforce. Although these industries attracted workers from around the world, the Chinese immigrants faced harsher than normal conditions. Anti-Chinese sentiment produced local laws which restricted Chinese wage earnings and attempted to isolate them and exclude them from California. These laws only found limited success until the mining and railroad industries no longer desired them as workers. Once this happened national leaders in the American Congress, in attempts to appease their constituents, passed the Chinese Exclusion Act. This paper looks to explore the relationship of the collapse of the mining and railroad industries and anti-Chinese sentiment with the passage Chinese Exclusion Act, as well as the American Chinese Diplomatic relationship as it evolved over the period of 1858 through 1880 and the United States of America moved towards exclusion as a domestic policy, which contradicted American Chinese diplomatic policy which wanted closer ties in an attempt to take advantage of Chinese trade.

\section{Historical Origins of Chinese Immigration to California}

Understanding the historical origins of Chinese immigration to California allows us to understand what sort of people came to the United States. Were these people who experienced a war-torn country, or were they enterprising individuals who saw an opportunity and took it?

In the late 1790's most of the population living on the North American continent who would have considered themselves citizens of the United States of America lived on the eastern coast. By the 1840's this had drastically changed as the US spread across the continent reaching California. In 1848, California was not much in terms of the economic and population giant it would become in the US. That would change with the discovery of gold at Sutter's Mill by James Marshall. This discovery would attract people from all over the world as they picked up their lives and settled in California in the search of wealth and better lives (Hannis, 248-73).

The economic boom experience in California would entice people to migrate, settle, and develop industry in this far corner of the North American continent. Hawaii and Australia's economic activity would also boom as California population caused the need for massive amounts of food, as in the early years, the population was primarily concerned with mining. Over the course of the first decade, the California gold rush, along with the Australian gold rush, nearly doubled the world supply of gold with a combined added value of $\$ 1.2$ billion dollars. This massive increase in wealth would create a migration pull that would be felt by many people around the world, including those living in southern China (Nash, 276-92).

During the first few years of the settling of California by the United States 90,000 Americans would head west to look for new lives. But also others from all around the world; including France, Ireland, China and Australia. The Chinese population exploded over the next ten years. In early 1850, a few hundred short of a thousand Chinese lived in California. By 1860, the Chinese population of California 10 percent of the total population, or 38,000 people (Hannis, 248-73).

With Chinese immigration to California we have seen the pull factors as gold was discovered in California creating economic opportunities for those willing to migrate and settles in the area. The push factors for Chinese immigration to California have their roots in a trans-pacific migration in the middle of the nineteenth century (Chen, 521-46 and Carson, 90-102).

In the traditional narrative Chinese migration to California is the result of wars against the Chinese empire, such as the Opium War, and internal conflict, such as the Taiping Rebellion. In his article "The Internal Origins of Chinese Emigration to California Reconsidered." Yong Chen argues that civil war, famine, and economic difficulties did not have as much of an impact on the regions of China where migrant's communities originated. Chinese immigration to California has its origins in the Pearl River Delta region. He also argues this region was not hit hard by civil war, famine, and economic difficulties but rather the Chinese people who left for California were taking advantage of economics opportunities that did not exist before. Yong points to the fact that millions of Chinese migrated to other parts of the world, particularly south-Asia, and only a small amount ended up in California. In Yong's argument, these people are not refugees, but rather middle class Chinese taking advantage of the opportunity to migrate that their parents never had. For Yong, the origins of the Chinese migration are not found in have terrible things were in China, but rather the economic prospects in other parts of the world, including California, this means the people coming to California are not the poorest, and the lowest of the Chinese social ladder. These immigrants are the middle class, and have used their wealth to migrant to different places not looking for refuge from a war, but economic and social advancement (Chen, 521-46). 


\section{Anti-Chinese Legislation in Early California}

Early attitudes towards Chinese immigration were often positive as businesses desired cheap labor. In 1850, many were praising the Chinese laborers for their willingness to work, saying, "We have a great deal of respect for the Chinese... and are pleased to find them of so quiet, peaceable [Sic], and industrious dispositions." During the course of the 1850's the local population no longer found Chinese immigration desirable. In 1859, an article, entitled CHINESE IMMIGRANTS published in Sacramento Daily Union, the author makes the point that California businesses have been using the influx of Chinese labors to reduce and undermine white wages in the state, pointing to the Chinese ability to work and live on lower wages, thereby reducing the wages of the mining industry ("The Common Council." California Digital Newspaper Collection. Daily Alta California 11 May 1850. Accessed on 4/20/2017. https://cdnc.ucr.edu/cgi-bin/cdnc?a=d\&d=DAC18500511.2.4\&srpos=11\&e=05-1850--06-1850--en--20-DAC-1-byDA-txt-txIN-Chinese+-------).

During the period of 1850-1880, Chinese immigration would not happen at a constant rate, it would shift up and down based on the market needs for cheap labor. As these markets needs changed they would often put pressure on locals. Chinese labors were often blamed for reducing and undermining white wages in California claiming, "Chinese labor comes in direct competition with that of Americans....and is .... public evil instead of a benefit" ("CHINESE IMMIGRANTS." California Digital Newspaper Collection. Sacramento Daily Union, 5 February 1859. Accessed on 4/20/2017. https://cdnc.ucr.edu/cgibin/cdnc?a=d\&d=SDU18590205.2.6\&srpos=1\&e=------185-en--20--1--txt-txIN-Chinese+workers-------). Because of these feelings anti-Chinese laws were introduced (Grant, 248-73).

Early anti-Chinese legislature came from the state legislature of California when in 1850, they passed a foreign miners' tax. This tax was not aimed at Chinese miners, but all foreign miners were required to pay the state $\$ 20$ per month to mine for gold. To understand how burdensome this tax could be, we can look at the records of Placer Mining which paid its miners a wage. As we can see in the image below as time as the 1850's advanced the average daily wage decreased. This applies that with time this foreign miners' tax became more and more of a burden. In 1850, a foreign miner could make perhaps earn more than $\$ 300$ in a month and pay the $\$ 20$ foreign miners' tax. By 1858, a foreign miner could only make perhaps $\$ 80$ a month. Chinese laborers were grouped with "unskilled miners" and were not paid the average but a much less (Kanazawa., 779-805 and Boswell, 352-71).

This law had a dual intention: it was meant to raise the states revenue force foreign miners to give up on the industry. However, because of the massive problems in the state's budget, it became easier to take advantage of Chinese labors and tax them at a higher rate, then simply force them out of the mining industry all together. Therefor over the course of the 1850 's foreign miners' tax was increased and decreased to maximize revenue on the part of the state. The foreign miners' tax provided the state of California a steady and reliable source of income over the next 15 years. Providing 10 percent of the state government's revenue (Kanazawa., 779-805 and Boswell, 352-71).

This foreign miners' tax happens within the context of the horrible economic situation the state government of California faced in its first decade of existence. The state could never keep revenues grow at the same pace as expenditures. In California's first year it collected almost no revenue, and racked up $\$ 350,000$ worth of debt. By 1853 , public debt of the state was up to $\$ 2,000,000$. With the economic opportunities created by the gold mining industry the state had to create a public infrastructure to meet the expanding population. But considering the nature of the gold mining industry where people would often pick up and move quickly to another location it made raising revenue by means of property or poll taxes difficult. By 1858, California had its first budget surplus, and from here on the financial situation of the state would improve. But it should be remembered that in the early years the state of California balanced its books in the backs of foreign miners with the foreign miners' tax (Kanazawa, 779-805).

Daily Alta California's article Exclusion of the Chinese highlights the extent the state of California used Chinese miners to balance the state's budget saying, "It is well known that more than half the taxes paid into the hands of the Tax Collectors in some of our counties has been contributed by its Chinese residents. In some it has equaled three-fourths [Sic] of all..." (California Digital Newspaper Collection. "Exclusion of the Chinese. Daily Alta California 28 July 1858. Accessed on 4/11/2017. https://cdnc.ucr.edu/cgi-bin/cdnc?a=d\&d=DAC18580728.2.12\&srpos=4\&e=-----185-en--20-DAC-1--txt-txIN-

Chinese+Exclusion------). By 1870, this would reach $\$ 5$ million in that year alone, and account for one fourth of the state's revenue. Although the original intention the foreign miners' tax was to expel foreign miners out of the mining industry, many quickly realized that instead of to expel foreign miners, they could simply use them. Therefore, the foreign miners' tax was adjusted as mining wages dropped. It was too important to the state to raise the revenue from the Chinese miners, and the state could not afford to make the tax unpayable (Lee, 90-102 and Kanazawa, 779-805). 
In 1858, California legislature, now with their books in the black, decided they no longer needed Chinese laborers and created a law which banned Chinese immigration to the state. Although this law was later declared unconstitutional, the public outcry over the law at the time gives us an understanding about the place of Chinese immigrants in those early days in California (Kanazawa, 779-805).

On 28 July, 1858, Daily Alta California ran an article entitled "Exclusion of the Chinese". In this article, the author claims, "The prohibition policy which has been too great a hobby with many of our politician" and that "During the last session of our Legislature, when the bill to prohibit the immigration of Chinese was introduced...chiefly because it was thought to be popular in certain localities." (California Digital Newspaper Collection. "Exclusion of the Chinese. Daily Alta California 28 July 1858. Accessed on 4/11/2017. https://cdnc.ucr.edu/cgi-bin/cdnc?a=d\&d=DAC18580728.2.12\&srpos=4\&e=-----185-en--20DAC-1--txt-txIN-Chinese+Exclusion------) This law to exclude Chinese immigrants was part of the pressure put on the state to limit Chinese immigration by the population because of the harm it was believed this influx of low wage laborers harmed the white population wage potential. This view was expressed in the Sacramento Daily Union, "The Chinaman, with his cheap living on rice and fish, can underwork the American, and is rapidly driving him out of the labor market." ("CHINESE IMMIGRANTS." California Digital Newspaper Collection. Sacramento Daily Union, 5 February 1859. Accessed on 4/20/2017. https://cdnc.ucr.edu/cgi-bin/cdnc?a=d\&d=SDU18590205.2.6\&srpos=1\&e=------185-en--20--1--txt-txIN-Chinese+workers------).

Despite the immigration ban being overruled as unconstitutional, because only the federal government had the power to legislate on immigration policy, legislative discrimination against Chinese immigrants did not stop, but continued into the 1860 's. By the mid 1860's through a combination of anti-Chinese laws and a decline in the gold mining industry greatly reduced Chinese immigration to the state of California. This decline in Chinese immigration would only turn around with the construction of the transcontinental railroad and the opportunities it presented for a new life for thousands of immigrants, creating a second wave of immigration (Carson, 80-102).

\section{Second Wave of Chinese Immigration to California}

The push for the construction of a transcontinental railroad required cheap and abundant labor. In the late 1860 's, this demand for labor once again fueled Chinese immigration to California. The importance of constructing the transcontinental railroad cannot be undermined. Some believe it was vital to the survival and growth of the American republic. In 1871, the transcontinental railroad was described by Russell Conwell in his book Why and How. Why the Chinese Emigrate, and The means they adopt for the purpose of reaching America in the following manner "Some men are foolish enough to believe that America owes its present unity as much to the construction of that track as to the armies under General Grant." To simulate the growth of transcontinental railroad the federal government provided land grants for every mile constructed, this resulted in railroad companies needing a vast workforce to take advantage of these land grants. Two main railroad companies, Union Pacific and Central Pacific, would be the primary companies to work on the transcontinental railroad (Carson, 80-102 and Conwell, 152).

Although the Union Pacific railroad had little trouble finding workers, this was not the case for the Central Pacific railroad. In 1865 , when its workforce planned a strike, the railroad decided to hire 50 to 100 Chinese laborers. From the Central Pacific's viewpoint, this worked out so well they hired 3,000 more by the end of the year. By the late 1860 's, $90 \%$ of Central Pacific's workforce was Chinese. They were considered harder workers, more dependable, and cheaper. The growth of the railroad increased demand for labor, and served as an incentive for Chinese laborers to come to the United States to fill this demand (Carson, 80-102.).

By 1870, The state of California was suffering labor shortage because of the introduction of the transcontinental railroad. In 1871, Russell Conwell, in his book Why and How. Why the Chinese Emigrate, and The means they adopt for the purpose of reaching America, described the labor shortage "At that time the isolated State of California was not sufficiently supplied with laborers to carry on its own liberal enterprises, and consequently was ill prepared to undertake the grading of a thousand miles of railroad." The transcontinental railroad opened opportunities for Chinese immigrants to work on the railroad, or work the newly available land. Conwell once again describes the event as "In this exigency an appeal was made to the Chinamen. " Come over and help us! "echoed across the Pacific. " We have money to spend, but no one to earn it," said the dispatches to Hongkong [Sic]." Over the next ten years' Chinese immigration once again surged. In the image above on Chinese migration we can see in the mid 1860's that there is once again a drastic raise in the rate of Chinese migration to the United States (Carson, 80-102 and Conwell, 152).

After the completion of the transcontinental railroad and other railroads, such as the Great Northern, Southern and Northern Pacific Railroads, many Chinese labors turned to working in California's agriculture industry. In 1860, there were 8 Chinese 
farmers out of 20,826 farmers listed. This jumps up to 346 of 24,061 in 1870 , and 1,434 of 43,489 farms by 1880 . This also does not count the thousands of Chinese laborers who did not own their own farms, but rather worked as laborers. Many farms listed 8 to 20 percent of their workforce being Chinese laborers. This shift to agricultural was because of decline in the mining and railroad industries. With these industries laying off thousands of workers, many looked to other means to support themselves (Carson, 80-102 and Tsu, 474-495).

\section{Violence against Chinese immigrants in the American West}

Discrimination against Chinese immigrants was everywhere in the American West, and often this discrimination turned violent. By building Chinatowns, Chinese immigrants attempted to wall themselves off from as much oppression and racial discrimination as possible. But many were attacked, beaten and often killed. This often took the form of the white population driving out the Chinese population, as in Shasta County, California where Chinese immigrants were rounded up and driven out of the county. Shasta County, California saw its Chinese population drop from 3,000, in 1853, to 160 by 1860 (Baxter, 2936 and Lee, 90-102).

On 4 June 1858, the Daily Alta California, published an account of crimes committed in the state. In this report, among others, was a report of a government official, a collector of the foreign miner's tax, beating and attempting to kill a Chinese man.

A Collector of the Foreign Miner's Tax was seen beating some Chinese on the north tide of Middle Yuba, in Sierra county, and was observed to push one of them into the water, and then threw stones at him as he lay helpless... (California Digital Newspaper Collection. "From our Evening Edition of Yesterday. Murder in Tulare Yalley." Daily Alta California. 4 June 1858. Accessed on 4/12/2017. https://cdnc.ucr.edu/cgi-bin/cdnc?a=d\&d=DAC18580604.2.2\&srpos=29\&e=------185-en--20-DAC-21-txt-txIN-Chinese+violence-------)

This violence against this Chinese man was very common throughout the American West, and would only get worse as more Chinese immigrants came to the US and interacted with more of the white population (Baxter, 29-36 and Lee, 90-102).

During the 1850's the white population of California was deeply worried that some of the Chinese population were members of secret Chinese societies. Often among these different secret Chinese societies conflict would emerge between them. In events such as the 1871 "Los Angeles Chinese Massacre" which led to the death of a member of the white population in Los Angeles this intensified the racial tension among the Chinese and white population (Paul Spitzerri. "Shall Law Stand for Naught?": The Los Angeles Chinese Massacre of 1871 at Trial." California Legal History 3, (January 2008): 185-224.). Other cases were often reported in the newspapers all over California, and for some these secret Chinese societies seemed to be everywhere. This irrational fear drove many to support anti-Chinese legislation (California Digital Newspaper Collection. "THE CHINESE CASE." Daily Alta California, 5 January 1854. Accessed on 4/12/2017. https://cdnc.ucr.edu/cgibin/cdnc?a=d\&d=DAC18540105.2.9\&srpos=2\&e=------185-en--20-DAC-1--txt-txIN-Chinese+killed-------).

Over the next two decades this violence against Chinese immigrants would continue up to and after the passage of the Chinese Exclusion Act. Similar acts of violence would continue to take place as Chinese workers were kicked out of towns, and sometimes killed. However, during the 1880's large anti-Chinese riots, such as in Rock Springs, Wyoming, required federal troops be called in to suppress rioters and return the area back to the control of the civil government. The large scale antiChinese riots, popular anti-Chinese sentiment held by many in the American West put pressure on the American Congress to find a solution to the problem. The solution the Congress settled on was exclusion. In 1859, this solution was popular, the Sacramento Daily Union article reading "this tide of Mongolian immigrants should be turned back upon its source." It just took the decline of the mining, railroad industries, and for the discussion of Chinese exclusion to reach the national level before the Chinese Exclusion Act could be passed (Lee, 90-102, Laurie, 22-29, Historical Census Statistics on the Foreign-born Population of the United States: 1850-1990. Working Paper No. 29,).

\section{Chinese-American Diplomatic history}

The Chinese Exclusion Act is an example of American domestic policy being in contradiction to its Foreign policy. The ChineseAmerican Diplomatic history before the Open-Door policy (1900-1901) can be summed up in a few treaties between the two powers. The Treaty of Wangxia (1844), the Treaty of Tianjin (1858), and The Burlingame-Seward Treaty (1868) are all examples of how the United States accomplished its Foreign policy goals of having closer and closer ties with China. Whereas the Chinese Exclusion Act severed the free movement of people between these nations, and pushed them apart (Keliher, 227-257).

The United States of America had a long interest in the China Trade. As the United States became more of a presence on the North American continent there arose the possibilities of taking part in the China trade. In 1843, under President John Tyler, after much debate, the US Congress approved funds to provide for a mission to negotiate a treaty between the US and China. 
The treaty produced form this mission was the Treaty of Wangxia. The primary propose of this treaty was to establish a relationship with the Chinese Qing Empire, and to provide legal protection for American citizens in China, stating, "All citizens of the United States in China peaceably attending to their affairs, being placed on a common footing of amity and goodwill with subjects of China" However, the Treaty of Wangxia does not contain any passage about the treatment of Chinese people in the United States. ${ }^{2}$

In 1858, The United States and China signed the Treaty of Tianjin. This treaty was a result of the Second Opium War, which the United States was a minor player. This war started over Great Britain and United States were unhappy over the Chinese government's refusal to adhere to the terms of the Treaty of Wangxia, stating "All citizens of the United States of America in China, peaceably attending to their affairs, being placed on a common footing of amity and good will with the subjects of China" ("Treaty of Tianjin (Tien-tsin), 1858". University of South California. USC US-China institute. Accessed on 4/12/2017. http://china.usc.edu/treaty-tianjin-tien-tsin-1858). From this quote, we see that it is not that different from the Treaty of Wangxia. The Treaty of Tianjin was intended to reaffirm the Chinese government to these principals of trade, and ensuring American citizens safety and access to trade while in China. The Treaty of Tianjin made the news back in California with many people celebrating the further opening of the China trade ("Daily Alta California. SAN FRANCISCO, TUESDAY. SEPT. 21, 1858." Daily Alta California, 21 September 1858. Accessed on 4/13/2017. https://cdnc.ucr.edu/cgi$\mathrm{bin} / \mathrm{cdnc}$ ?a=d\&d=DAC18580921.2.11\&srpos=7\&e=------185-en--20-DAC-1--txt-txIN-Chinese+Exclusion-------).

The Burlingame-Seward Treaty goes beyond the Treaty of Wangxia and the Treaty of Tianjin as it addresses protections of Chinese subjects living in and coming to the United States, saying, "Chinese subjects visiting or residing in the United States shall enjoy the same privileges, immunities, and exemptions in respect to travel or residence as may there be enjoyed by the citizens or subjects of the most favoured nation [Sic]." ("Text of the treaty between China \& the United States". University of California. Accessed on 4/13/2017. http://content.cdlib.org/ark:/13030/hb4m3nb03h/?order=5\&brand=calisphere) The Burlingame-Seward Treaty opened the door to increased Chinese immigration to the United States. This treaty made both sides committed to the free movement of people between their borders. This treaty accelerated Chinese immigrations to the American west.

The Burlingame-Seward Treaty would allow the free movement of people between the Chinese empire and the USA, and would quicken Chinese immigration. But the Burlingame-Seward Treaty would also end Chinese immigration to the US. By accelerating Chinese immigration racial discrimination against Chinese immigrants became so intense, that Chinese exclusion became a political platform in the 1870's and 1880's ("Chinese Immigration and the Chinese Exclusion Acts" Office of the Historian. US Department of State. Accessed on 4/13/2017. https://history.state.gov/milestones/1866-1898/chineseimmigration).

\section{Chinese Exclusion}

From our earlier discussion, on early attempts by the state of California to limit Chinese immigration, we have seen how some of the anti-Chinese legislation was crafted. Attempts by the state to prevent Chinese immigration were declared unconstitutional on account that the federal government, not the states controlled immigration policy. Because of the AntiChinese sentiment that existed, and because of the growing violence, Chinese exclusion became a political platform in the 1870's by the democrats. Over the decade, they would push for, and succeed in amending the Burlingame-Seward Treaty, and excluding the section on allowing free movement of people between the USA and China ("Chinese Immigration and the Chinese Exclusion Acts" Office of the Historian. US Department of State. Accessed on 4/13/2017. https://history.state.gov/milestones/1866-1898/chinese-immigration, ).

In 1879, Democrats passed a bill limiting the numbers of Chinese immigrants to 15 immigrants per ship entering the USA. President Rutherford B. Hayes vetoed, because it violated the Burlingame-Seward Treaty. While Republicans supported free immigration, the Democrats supported exclusion, and they had a foot hold in the American West. President Rutherford B. Hayes did not oppose limiting Chinese immigration; he just didn't want the democrats to get the credit. Hayes decided he

\footnotetext{
2"The Opening to China Part I: the First Opium War, the United States, and the Treaty of Wangxia, 1839-1844" Office of the Historian. US Department of State. Accessed on 4/12/2017. https://history.state.gov/milestones/1830-1860/china-1

University of South California. USC US-China institute. "Treaty of Wangxia (Treaty of Wang-hsia), May 18, 1844" Accessed on 4/12/2017.

http://china.usc.edu/treaty-wangxia-treaty-wang-hsia-may-18-1844

Macabe Keliher. "Anglo-American Rivalry and the Origins of U.S. China Policy." Diplomatic History 31, no. 2 (April 2007): 227-257.

University of South California. USC US-China institute. "Treaty of Wangxia (Treaty of Wang-hsia), May 18, 1844" Accessed on 4/12/2017.

http://china.usc.edu/treaty-wangxia-treaty-wang-hsia-may-18-1844

"The Opening to China Part I: the First Opium War, the United States, and the Treaty of Wangxia, 1839-1844" Office of the Historian. US Department of State. Accessed on 4/12/2017. https://history.state.gov/milestones/1830-1860/china-1
} 
would attempt to limit Chinese immigration by renegotiating the terms of the Burlingame-Seward Treaty ("Chinese Immigration and the Chinese Exclusion Acts" Office of the Historian. US Department of State. Accessed on 4/13/2017. https://history.state.gov/milestones/1866-1898/chinese-immigration).

The 1880 Angell Treaty, revisited sections of the Burlingame-Seward Treaty and allowed the USA to limit Chinese immigration. The Angell Treaty gave the USA the right to limit, suspend and regulate Chinese immigration to the USA. The Democrats where not happy as it did not exclude all Chinese immigration. So, in 1882, congress passed the Chinese Exclusion Act which suspended Chinese immigration for a period of ten years. This time President Rutherford B. Hayes had left office and the new President, Chester Arthur, no legal reason to veto the bill, and he did support limiting Chinese immigration. This became the first time the United States of American would ban immigration because of the ethnic identity and national origin ("Chinese Immigration and the Chinese Exclusion Acts" Office of the Historian. US Department of State. Accessed on 4/13/2017. https://history.state.gov/milestones/1866-1898/chinese-immigration

Trubowitz, Peter, and Seo Jungkun. "The China Card: Playing Politics with Sino-American Relations." Political Science Quarterly (Academy Of Political Science) 127, no. 2 (Summer2012 2012): 189-211.)

\section{Conclusion}

The American West does bring forth images and ideals of American values, but it also represents the worst of American values as Chinese immigrants sought out opportunities to create new lives for themselves working in gold mines, the railroad, or agriculture. These people often found hate and exclusion as many were forced to live in Chinatowns for fear of their lives. Many people, such as those who worked at the Daily Alta California in the 1850's were in favor of Chinese immigration because of the freedoms inscribed in the American Constitution. However, as immigration increased and the anti-Chinese rhetoric and violence became more intense as politicians used exclusion as a political platform to earn political victories over their rivals.

The passage of the United States of America's first law banning the immigration of an entire people was an outgrowth of the collapse of the Chinese labor market as California's gold mines and railroad industries declined and racial discrimination towards people of Chinese descent. Despite American and Chinese diplomatic relations over the period of 1858 through 1880 , which moved towards greater interaction between the two nations, by 1880 Chinese exclusion had become a political issue that the democrats, and those who held anti-Chinese feelings, would not give up on until exclusion became law.

From Mark Kanazawa's article "'Immigration, Exclusion, and Taxation: Anti-Chinese Legislation in Gold Rush California" Mark Kanazawa's to Erika Lees' The making of Asian America: a History, The Chinese Exclusion Act has been used by historians as a prism to understand different aspects of the American history from social history, immigration history, or diplomatic history. These different viewpoints have added to our collective knowledge of the context of such an interesting period in our history. However, the core issue within these debates over the historiography is what kind of nation is the United States? Is it a nation built on a foundation of freedom or oppression? This gets at the heart of the fundamental contradiction in American history. That a free nation can be built on slavery, that a nation on immigrants can exclude immigrants. The Chinese Exclusion Act is part of that fundamental contradiction in American history (Kanazawa, 779-805).

For a people whose forefathers came to the continent and took possession without asking permission of its occupants...had proclaimed to the world that this should be a land free to all, a home for the oppressed, a refuse for the persecuted, an asylum for ... advocate and adopt a policy which would have excluded themselves and their ancestors...(California Digital Newspaper Collection. "Exclusion of the Chinese. Daily Alta California 28 July 1858. Accessed on 4/11/2017. https://cdnc.ucr.edu/cgi-bin/cdnc?a=d\&d=DAC18580728.2.12\&srpos=4\&e=------185-en--20-DAC-1--txt-txIN-

Chinese+Exclusion-------)

\section{References}

[1] Annis, M. (2010). The Chinese Question" and the Canada-US Border, 1885: "Why don't Governor Squire send his troops to Semiahmoo to prevent the twelve or fifteen thousand pagans from crossing our borders from British Columbia? American Review Of Canadian Studies 40(3), 351-361

[2] Baxter, R. (2008). The Response of California's Chinese Populations to the Anti-Chinese Movement. Historical Archaeology, 42(3), 2936.

[3] Boswell, T. (1986). A Split Labor Market Analysis of Discrimination Against Chinese Immigrants, 1850-1882. American Sociological Review 51(3), 352-71

[4] Calavita, K. (2000). The Paradoxes of Race, Class, Identity, and Passing: Enforcing the Chinese Exclusion Acts, 1882-1910. Law \& Social Inquiry 25(1). 
[5] Carson, S. (2005). Chinese Sojourn Labor and the American Transcontinental Railroad. Journal of Institutional and Theoretical Economics (JITE) / Zeitschrift Für Die Gesamte Staatswissenschaft 161(1), 80-102.

[6] Chen, Y. (1997). The Internal Origins of Chinese Emigration to California Reconsidered. The Western Historical Quarterly, 28(4), 52146.

[7] Chinese Immigration and the Chinese Exclusion Acts. Office of the Historian. US Department of State. Accessed on 4/13/2017. https://history.state.gov/milestones/1866-1898/chinese-immigration

[8] Conwell, R. (1871) Why and How. Why the Chinese Emigrate, and The means they adopt for the purpose of reaching America. Boston: Lee and Shepard, Publishers, 1871.

[9] Cook-Martín, D., and Gerald, D. (2010). Liberalism and the Limits of Inclusion: Race and Immigration Law in the Americas, 1850-2000. The Journal of Interdisciplinary History 41(1), 7-25.

[10] Department of Homeland Security (DHS), Office of Immigration Statistics. 2014. 2013 Yearbook of Immigration Statistics. Washington, DC: DHS Office of Immigration Statistics. https://www.dhs.gov/immigration-statistics/yearbook/2013.

[11] Dippie, B. (1989). American Wests: Historiographical Perspectives. American Studies Internationa,I 27(2), 3-25.

[12] Foreign Relations of the United States. https://history.state.gov/historicaldocuments

[13] Gibson, C. and Lennon, E. (1999). Historical Census Statistics on the Foreign-born Population of the United States: 1850-1990. Working Paper No. 29, U.S. Census Bureau, Washington, DC. https://www.census.gov/population/www/documentation/twps0029/twps0029.html.

[14] Hannis, G. (2011). A Comparative Analysis of Nineteenth-Century Californian and New Zealand Newspaper Representations of Chinese Gold Miners. The Journal of American-East Asian Relations, 18(3/4), 248-73.

[15] Hester, T. (2010) Protection, Not Punishment: Legislative and Judicial Formation of U.S. Deportation Policy, 1882-1904." Journal of American Ethnic History, 30(1), 11-36.

[16] Jun, H. (2006). Black Orientalism: Nineteenth-Century Narratives of Race and U.S. Citizenship. American Quarterly, 58(4), $1047-066$.

[17] Kanazawa, M. (2005). Immigration, Exclusion, and Taxation: Anti-Chinese Legislation in Gold Rush California. The Journal of Economic History, 65( 3). 779-805.

[18] Keliher, M. (2007). Anglo-American Rivalry and the Origins of U.S. China Policy. Diplomatic History, 31(2), $227-257$.

[19] Laurie, C. (1990). The Chinese Must Go: The United States Army and the Anti-Chinese Riots in Washington Territory, 1885-1886. The Pacific Northwest Quarterly, 81(1), 22-29.

[20] Lammers, J. (1988). The Accommodation of Chinese Immigrants in Early California Courts. Sociological Perspectives, 31(4), $446-65$.

[21] Lee, E. (2002). Enforcing the Borders: Chinese Exclusion along the U.S. Borders with Canada and Mexico, 1882-1924. The Journal of American History, 89(1), 54-86.

[22] Lee, E. (2015). The making of Asian America: a history. New York : Simon \& Schuster.

[23] Roske, R. (1963). The World Impact of the California Gold Rush 1849-1857. Arizona and the West, 5(3), 187-232.

[24] Nash, Gerald D. (1998). A Veritable Revolution: The Global Economic Significance of the California Gold Rush. California History, 77(4), 276-92.

[25] Ngai, M. (2004). Impossible Subjects: Illegal Aliens and the Making of Modern America. Princeton and Oxford: Princeton University Press.

[26] Greenfield, M. (2012). Benevolent Desires and Dark Dominations: The Pacific Mail Steamship Company's SS City of Peking and the United States in the Pacific 1874-1910. Southern California Quarterly, 94(4), 423-78.

[27] Matsubara, H. (2003) Stratified Whiteness and Sexualized Chinese Immigrants in San Franciso: The Report of the California Special Committee on Chinese Immigration in 1876. American Studies International, 41(3), 32-59. America: History and Life with Full Text, EBSCOhost (accessed March 7, 2017).

[28] Peffer, G. (1992). From under the Sojourner's Shadow: A Historiographical Study of Chinese Female Immigration to America, 18521882. Journal of American Ethnic History, 11(3), 41-67.

[29] Text of the Chinese Exclusion Act. (2008) Visions \& Divisions: 7-10.

[30] Treaty of Wangxia (Treaty of Wang-hsia), May 18, 1844. University of South California. USC US-China institute. Accessed on 4/12/2017. http://china.usc.edu/treaty-wangxia-treaty-wang-hsia-may-18-1844

[31] Text of the treaty between China \& the United States. University of California. Accessed on 4/13/2017. http://content.cdlib.org/ark:/13030/hb4m3nb03h/?order=5\&brand=calisphere

[32] The Amendment of the Chinese Exclusion Act. (1893). American Advocate of Peace, 55(12), 277-78.

[33] The Supreme Court and the Chinese Exclusion Act. (1893). American Advocate of Peace, 55(6), 130-31.

[34] Treaty of Tianjin (Tien-tsin), 1858. University of South California. USC US-China institute. Accessed on 4/12/2017. http://china.usc.edu/treaty-tianjin-tien-tsin-1858

[35] The Burlingame-Seward Treaty. (1868). Office of the Historian. US Department of State. Accessed on 4/13/2017. https://history.state.gov/milestones/1866-1898/burlingame-seward-treaty

[36] The Opening to China Part I: the First Opium War, the United States, and the Treaty of Wangxia, 1839-1844. Office of the Historian. US Department of State. Accessed on 4/12/2017. https://history.state.gov/milestones/1830-1860/china-1

[37] The Opening to China Part II: the Second Opium War, the United States, and the Treaty of Tianjin, 1857-1859. Office of the Historian. US Department of State. Accessed on 4/12/2017. https://history.state.gov/milestones/1830-1860/china-2

[38] Tsu, C. (2006). Independent of the Unskilled Chinaman: Race, Labor, and Family Farming in California's Santa Clara Valley. Western Historical Quarterly, 37(4), 474-495. 
[39] Trubowitz, P., and Seo J. (2012). The China Card: Playing Politics with Sino-American Relations. Political Science Quarterly (Academy Of Political Science), 127,(2), 189-211.

[40] Spitzerri, P. (2008). Shall Law Stand for Naught?: The Los Angeles Chinese Massacre of 1871 at Trial." California Legal History ,3: 185224.

[41] Salyer, L. (1989). Captives of Law: Judicial Enforcement of the Chinese Exclusion Laws, 1891-1905. Journal Of American History, 76(1), 91-117. America: History and Life with Full Text, EBSCOhost (accessed March 7, 2017).

[42] Pegler-Gordon, A. (2006). Chinese Exclusion, Photography, and the Development of U.S. Immigration Policy. American Quarterly, 58(1), 51-77. 